\title{
Kompetencje miękkie \\ w międzynarodowym kształceniu \\ zawodowym na przykładzie \\ szkolenia EDTECH
}

DOI: 10.47050/65591876.100-115

Monika Tomczyk

Boosting Business Integration Through Joint Vocational Education and Training (BBVET) to projekt badawczo-rozwojowy mający na celu wzmocnienie umiędzynarodowienia kształcenia zawodowego (VET) w regionie Morza Bałtyckiego. Projekt jest wspófinansowany z funduszy INTERREG South Baltic Programme i stanowi część strategii Unii Europejskiej dla regionu Morza Bałtyckiego. BBVET rozwinął i wdrożył dziesięciomiesięczny międzynarodowy program kształcenia wykwalifikowanej kadry zawodowej w kierunku EDTECH. Oferuje on firmom możliwość dzielenia się doświadczeniami z 40 młodymi, zmotywowanymi ludźmi z pięciu krajów: Danii, Litwy, Niemiec, Polski i Szwecji. Projekt BBVET działa jako rodzaj agencji mobilności zawodowej i wspiera pobyt za granicą we wszystkich trzech fazach: przygotowania, wdrożenia i kontynuacji - nie tylko organizacyjnie, ale też finansowo. Niniejszy rozdział przedstawia model umiędzynarodowienia edukacji - unikalny, innowacyjny program nauczania opracowany z uwzględnieniem wymogów kształcenia w kierunku EDTECH oraz potrzeb rynku pracy. Ten program nauczania kładzie duży nacisk zarówno na umiejętności twarde, jak i na rozwój umiejętności miękkich.

\section{Słowa kluczowe:}

\section{mobilność}

edukacja zawodowa

umiejętności miękkie

umiędzynarodowienie edukacji

EDTECH 


\section{Soft skills in the International \\ Vocational Education \\ - an example of EDTECH}

DOI: $10.47050 / 65591876.100-115$

Monika Tomczyk

Boosting Business Integration Through Joint Vocational Education and Training (BBVET) is a research and development project aiming to strengthen the internationalization of Vocational Educational Training (VET) in the Baltic Sea Region. It is funded by the INTERREG South Baltic Programme and embedded in the European Union strategy for the Baltic Sea Region. South Baltic is an interregional labour market for international business cooperation with access to a new skilled and qualified labour force. BBVET International Training Year is a ten-month programme which offers companies an opportunity to share experiences with young motivated people from five countries in the EdTech sectors, involving 40 students and 5 countries, namely: Denmark, Germany, Lithuania, Poland and Sweden. The BBVET project is as a kind of occupational mobility agency and supports the stay abroad in all three phases: preparation, implementation, and follow-up - not exclusively organizationally, but also financially. This paper presents a model of internationalization, the unique, innovative curriculum developed for the EDTECH education as well as need of market. Innovative curriculum put as much emphasis on the hard skills as well to the soft skills development.

\section{Keywords:}

mobility

VET Education

soft skills

internationalization of education

EDTECH 


\section{Wprowadzenie}

Istnieje wiele wyników badań w dziedzinie kształcenia i szkolenia zawodowego, zarówno krajowych, jak i międzynarodowych. Jednym $z$ nich jest Boosting Business Integration Through Joint Vocational Education and Training (BBVET). BBVET działa jak swego rodzaju agencja mobilności zawodowej i wspiera pobyt za granicą we wszystkich trzech fazach: przygotowania, wdrożenia i kontynuacji mobilności-nie tylko organizacyjnie, ale również finansowo. Według definicji przedstawionej w projekcie agencje mobilności zawodowej to jednostki wspierające obecnych lub przyszłych uczniów kierunków zawodowych w dostosowywaniu się do wymogów dynamicznego rynku pracy. Ułatwiają dokształcenie się lub zmianę zawodu, nabycie kompetencji międzykulturowych czy praktycznej wiedzy wymaganej w konkretnym zawodzie. W rozdziale przedstawiono model umiędzynarodowienia edukacji zawodowej, który jest innowacyjnym, unikalnym programem nauczania w kierunku EDTECH, który bierze pod uwagę potrzeby studentów, szkół oraz rynku pracy. Program ten może być postrzegany jako innowacyjny z dwóch powodów. Po pierwsze, ponieważ kładzie równie duży nacisk na rozwijanie zarówno umiejętności zawodowych, jak i kompetencji miękkich. Po drugie, dlatego że w jego ramach po raz pierwszy przeprowadzono edukację zawodową w zakresie EDTECH na arenie międzynarodowej.

\section{Innowacyjne kształcenie zawodowe w środowisku międzynarodowym}

Definicja kształcenia i szkolenia zawodowego jako sektora systemu edukacji stwarza problem. W większości przypadków kształcenie ogólne i akademickie jest postrzegane jako rozwijające umiejętności analityczne, wiedzę i umiejętność krytycznego myślenia, natomiast kształcenie i szkolenie zawodowe - jako zwiększające zdolności praktyczne, dzięki umożliwieniu zdobycia doświadczenia i praktycznemu rozwiązywaniu problemów. To proste rozróżnienie nie zawsze znajduje zastosowanie w praktyce. Dobremu mechatronikowi lub mechanikowi, który musi dokonywać rutynowych rozstrzygnięć, aby rozwiązywać problemy, potrzebne są umiejętność myślenia krytycznego i umiejętności analityczne. Podobnie, dobry projektant potrzebuje różnorodnych umiejętności praktycznych, aby nauczyć się obsługi klienta. Aby wypełnić lukę w edukacji zawodowej 
i przetestować różne podejście do kształcenia zawodowego, opracowano i wdrożono projekt BBVET. Stanowi on platformę współpracy między studentami - potencjalnymi pracownikami i pracodawcami. Platforma jest łącznikiem między studentami a rynkiem pracy - zapewnia aktualne szkolenia i przyuczanie do zawodu dostosowane do indywidualnych potrzeb.

W edukacji innowacyjność definiuje się zwykle niepoprawnie lub niekonsekwentnie, co utrudnia zrozumienie sposobu wykorzystania innowacji do osiągnięcia lepszych wyników w nauczaniu. Innowacje w kształceniu dzięki dostarczaniu nowych metod sprzyjają rozwiązywaniu problemów systemu edukacji, usuwaniu (istniejących od dawna) barier w realizacji działań dydaktycznych i edukacyjnych, a także budują zdolności wdrożeniowe. Robią to dzięki:

$\rightarrow$ kreowaniu nowych rozwiązań lub usunięciu tradycyjnych barier dla istniejących działań w zakresie nauczania i uczenia się;

$\rightarrow$ określeniu wcześniej niezidentyfikowanej potrzeby lub bariery, a następnie wzmocnieniu nauczania i uczenia się za sprawą innowacyjnego podejścia, ponownej analizie czynnika ograniczającego i odpowiednie reagowanie;

$\rightarrow$ wprowadzeniu nowych możliwości poprawy nauczania i uczenia się w celu osiągania lepszych wyników; oraz

$\rightarrow$ umożliwieniu systemowi edukacji dostosowania się do nowych ścieżek kształcenia studentów.

Reasumując, innowację w edukacji utożsamia się z poprawą systemu kształcenia, ale nie jest to poprawa przez zwykłą biegłość w standardowej praktyce (Redding, Twyman, Murphy 2013).

W latach 2017-2019 konsorcjum BBVET skupiło się na rozwoju modułowych międzyregionalnych programów kształcenia i szkolenia zawodowego w regionie południowego Bałtyku. Celem było opracowanie programu szkoleniowego, który z jednej strony uwzględniałby kontynuację kształcenia zawodowego i struktur szkoleniowych w sektorze EDTECH, z drugiej zaś, stworzyłby unikalny międzyregionalny system edukacji, wykorzystujący specyfikę międzynarodową tego regionu. Od stycznia 2018 r. testowano międzynarodowy program VET - EDTECH. Faza testowa otwarta była dla młodych ludzi w wieku od 18 do 35 lat, w tym siedmiu studentów z Polski. Rysunek 1 przedstawia fazy tworzenia i testowania programu kształcenia EDTECH. 
Rysunek 1. Proces tworzenia i wdrażania programu kształcenia BBVET

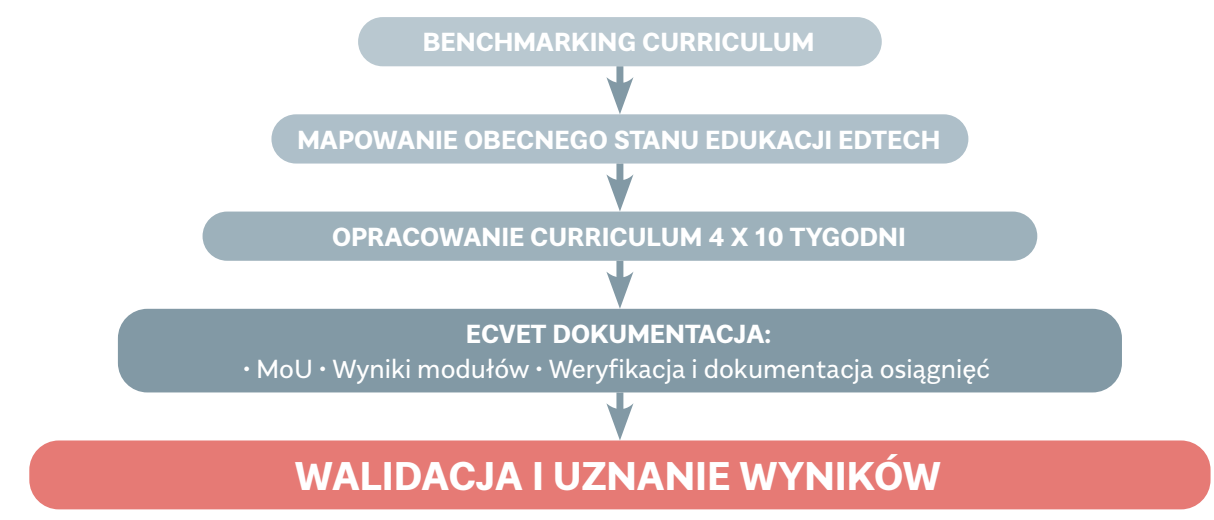

Źródło: opracowanie własne.

Proponowany system edukacji musiał uwzględniać systemy edukacyjne w poszczególnych krajach. Oprócz klasycznego szkolnego kształcenia zawodowego w Polsce, Danii, Szwecji i na Litwie, należało wziąć pod uwagę niemiecki model kształcenia zawodowego. Tak zwany system dualny obejmuje połączenie kształcenia teoretycznego i praktycznego kształcenia zawodowego, które jest de facto wstępnym kształceniem zawodowym. Osoby odbierające edukację zawodową w systemie dualnym zazwyczaj odbywają trzyletni staż w szkole i w miejscu pracy zgodnie $z$ wybranym przez siebie zawodem lub w specjalistycznych szkołach zawodowych z nadzorem państwa. Zarówno partnerzy z poszczególnych krajów związkowych, jak i na szczeblu państwa zaangażowani są $w$ dualny system edukacji w Niemczech. W procesie tym uczestniczą zatem następujące podmioty: państwo, partnerzy społeczni - przedstawiciele pracodawców i pracowników, oraz izby handlowe i przemysłowe lub izby rzemieślnicze. System dualny kształcenia zawodowego jest nieelastyczny i koncentruje się na rynku lokalnym.

Mimo to stworzono i wdrożono model pobudzania biznesu dzięki edukacji VET. Kształcenie BBVET nawiązuje do modelu opartego na metodyce zarządzania cyklem projektu (PCM) i składa się z ośmiu etapów realizacji programu kształcenia. Etapy te zostały przedstawione 
na rysunku 2. Etap 1 to marketing i rekrutacja kandydatów w pięciu krajach biorących udział w projekcie. Etap 2 - określenie indywidualnych celów edukacyjnych kandydatów. Etap 3 - dopasowanie do indywidualnych potrzeb przez dobranie odpowiednich firm oraz odzwierciedlenie ich w tematyce szkoleń. Etap 4, który nakłada się na etapy 5, 6 i 7, to indywidualny coaching, czyli monitorowanie i wzmacnianie procesu rozwoju i zdobywania nowych kwalifikacji podczas szkoleń, stażu. Etapy 5, 6, 7 to elementy etapu kształcenia, po których następuje walidacja osiągniętych wskaźników.

Rysunek 2. Model kształcenia BBVET

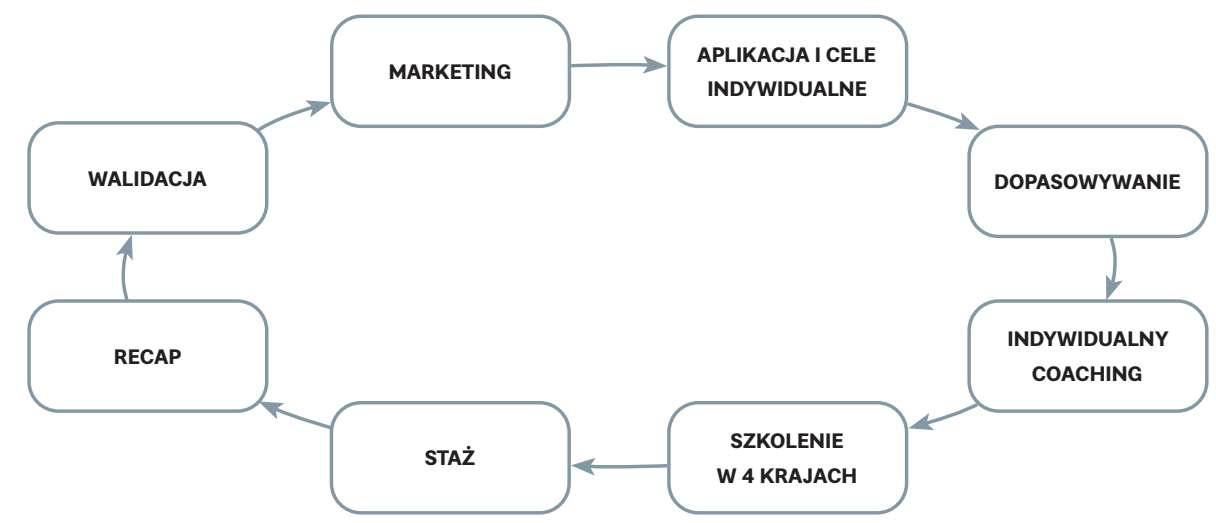

Źródło: opracowanie własne.

Programy kształcenia i szkolenia zawodowego BBVET łączą w sposób unikalny umiejętności twarde i miękkie, z uwzględnieniem wyjątkowych ponadnarodowych doświadczeń edukacyjnych. Aby prześledzić indywidualny rozwój osobistych umiejętności miękkich po roku szkolenia BBVET w projekcie wykorzystano narzędzie do ich pomiaru. Zdecydowano się utworzyć grupę referencyjną w celu określenia poziomu rozwoju studentów, którzy pozostali w kraju, i porównania ich z wynikami uczniów uczestniczących w programie. Dlatego też badanie obejmuje zarówno studentów z tzw. grupy referencyjnej w każdym kraju partnerskim (Dania, Litwa, Niemcy, Polska, Szwecja), jak i studentów BBVET. 
Pomiar zmian, jakie zachodzą wśród uczestników szkoleń i nabytych przez nich kompetencji, daje instytucjom szkoleniowym możliwość wyróżnienia się i zróżnicowania w porównaniu z innymi programami edukacyjnymi, a tym samym przedstawienia bardzo rzetelnej i realnej oferty dla przyszłych studentów i przedsiębiorców. Jak już wspomniano, model BBVET opiera się na zarządzaniu cyklem kształcenia, którego etapy przedstawiono na rysunku 2. Każdy cykl jest ewaluowany i wpływa na zmiany podejmowane w kolejnym obrocie. Taka struktura umożliwia wypełnienie luk i niedoskonałości poprzedniej rotacji. Każdy obrót odbywa się w ośmiu etapach:

$\rightarrow$ Marketing studencki - rozpowszechnianie informacji o szkoleniach wśród studentów potencjalnie zainteresowanych edukacją EDTECH i mechatroniką.

$\rightarrow$ Aplikacja z indywidualnymi celami - zainteresowane osoby rejestrują się na platformie. Z każdą z nich przeprowadza się indywidualny wywiad, którego celem jest określenie poziomu wiedzy na dany temat, a także gotowości do współpracy w grupie i podjęcia edukacji międzynarodowej, która wiąże się z mobilnością i pobytami za granicą.

$\rightarrow$ Dopasowywanie się - uwzględnia się indywidualne potrzeby każdego uczestnika. Jego ścieżka rozwoju i proces uczenia się są dobierane w taki sposób, aby mógł osiągnąć cele indywidualne.

$\rightarrow$ Indywidualny coaching - dostarcza sposobów na aktywizację samoświadomości ucznia, jego własnych umiejętności rozwiązywania problemów i pomaga w osiągnięciu celu. Trener, zamiast udzielania rad i pomocy - w postaci gotowych odpowiedzi i rekomendowania działań, zadaje uczniom pytania, które prowadzą ich do sformułowania własnych odpowiedzi i planowania działań prowadzących do osiągnięcia celu. Coaching wymaga specjalnej postawy ze strony trenera - postawienia ucznia w centrum procesu rozwoju (gdzie znajduje się także i sam coach).

$\rightarrow$ Relacja trener - student wymaga zaufania, które powinno być utrzymane bez względu na to, jak bardzo trudny może okazać się proces. Ważne jest, aby trener stosował specjalne metody dostosowane do zdolności ucznia i miał takie umiejętności, jak aktywne słuchanie. Trenerzy BBVET korzystają z narzędzia zwanego integralną mapą coachingu, które pomaga monitorować 
i dokumentować proces z całej dostępnej perspektywy, korzystają również z list kontrolnych oraz z modelu biznesowego You (Ostervalder 2010). Coaching jako metoda zaangażowania zatem bardzo różni się od pozostałych metod, takich jak doradztwo czy wykłady.

$\rightarrow$ Zaufanie pozwala trenerowi zadawać głębsze pytania, stawiać wyzwania i motywować ucznia oraz wreszcie trener może uszeregować i usystematyzować hierarchie między różnymi punktami widzenia - co jest szczególnie potrzebne w okresie długotrwałego przebywania poza domem.

$\rightarrow$ Kursy wprowadzające w każdym kraju - kurs trwa 40 tygodni. Prowadzony jest w czterech krajach, w każdym studenci spędzają dziesięć tygodni. Konsorcjum opracowało międzynarodowy program nauczania z zakresu mechatroniki oraz unikalny, oryginalny kurs EDTECH. Wszystkie cztery części kursu są ze sobą powiązane i tworzą dobrze zaprojektowaną układankę, która pomaga studentom rozwijać się indywidualnie i w grupach. Oprócz umiejętności twardych kurs obejmuje warsztaty umiejętności miękkich dostosowanych do procesu grupowego Tuckmana. Cztery fazy procesu grupowego to: formowanie się grupy (forming), konflikt w grupie (storming), powstanie reguł funkcjonowania grupy (norming) i działanie grupy (performing).

$\rightarrow$ Dla każdej fazy opracowano zestaw zajęć, które pomagały studentom w odnalezieniu się w nowej sytuacji, a także w zrozumieniu dynamiki grupy i świadomym uczestniczeniu w procesie.

$\rightarrow$ Praktyki-kurs oznacza zarówno zdobycie wiedzy teoretycznej, jak i współpracę z biznesem. Studenci zdobywają doświadczenie w pracy z klientami biznesowymi.

$\rightarrow$ Podsumowanie - dwudniowa prezentacja wyników osiąganych przez studentów w danym kraju. Na podsumowanie zaprasza się przedstawicieli potrójnej helisy - biznesu, nauki i polityków. Ponieważ projekt na każdym etapie jest inny, dokonuje się oceny danego okresu.

$\rightarrow$ Walidacja -działania mające na celu potwierdzenie w udokumentowany i spójny sposób, że procedury, procesy, sprzęt, materiały, działania i systemy rzeczywiście prowadzą do założonych wyników. 


\section{Pomiar wpływu umiejętności miękkich na edukację}

Trudna i gwałtownie zmieniająca się sytuacja dzisiejszej gospodarki powoduje, że nowi absolwenci nie są już usatysfakcjonowani pozyskaną w systemie edukacji wiedzą akademicką, tym bardziej że studenci potrzebują doskonalenia umiejętności, co zwiększy ich szanse na dobre zatrudnienie (Wilson 2011). Czym są "umiejętności miękkie" i dlaczego są one tak ważne? W trakcie szkolenia studenci zdobywają wiele umiejętności zawodowych, co oznacza, że są praktykantami. Stają się częścią wykwalifikowanej siły roboczej potrzebnej w gospodarce. Aby zarządzać „twardymi umiejętnościami”, muszą również nabyć wiele "umiejętności miękkich". Te, które ostatecznie pozyskają, będą wynikać $\mathrm{z}$ ich indywidualnych predyspozycji.

Istnieje sześć umiejętności miękkich, które mogą decydować o tym, jaki może być nasz wkład w pracę dla danego pracodawcy, a tym samym, w jaki sposób możemy w pełni wykorzystać wiedzę zawodową i stać się wykwalifikowaną siłą roboczą. Są to:

$\rightarrow$ komunikatywność,

$\rightarrow$ zdolność do współpracy,

$\rightarrow$ zapał do nauki,

$\rightarrow$ postawa prospołeczna,

$\rightarrow$ dojrzałość,

$\rightarrow$ zdolność do rozwiązywania problemów (National Skills Task Force 2000).

Pracodawcy wskazali, że absolwenci, którzy obecnie wchodzą na rynek pracy, nie posiadają takich umiejętności miękkich (Woo 2006). Na przykład w niektórych zawodach bardzo ważne jest, aby umieć współpracować, być prospołecznym i komunikatywnym, ale inne zawody będą wymagały innych umiejętności miękkich, takich jak większa niezależność, dojrzałość i zdolność do rozwiązywania problemów. Ponadto wiedza, odpowiednia postawa i umiejętności wydają się decydujące w miejscu pracy, które ostatecznie kształtuje studenta i sprawia, że jest chętny do rozwijania się i pogłębiania swoich kompetencji (Harvey, Locke, Morey 2002).

W ostatnich latach nastąpiła zasadnicza zmiana wymagań, które pracodawcy stawiają kandydatom do pracy. Przedkładają oni umiejętności miękkie nad umiejętności techniczne (Judhi, Pa'wan, Othman, Moksin 2010). Jak wskazuje Payne (2000), to właśnie te umiejętności 
osobiste są teraz, przynajmniej teoretycznie, najbardziej poszukiwane przez pracodawców (Department for Education and Employment 2008).

W celu zmierzenia i oceny umiejętności miękkich w międzynarodowym programie nauczania zastosowano klasyczny czteropoziomowy model oceny (Kirkpatrick 2006):

$\rightarrow$ 1. postawa ucznia, tzn. poziom jego motywacji, a tym samym zdolność do rozwiązania zadania;

$\rightarrow$ 2. wiedza, którą student musi posiadać, aby wykonać zadanie;

$\rightarrow$ 3. zachowanie, tzn. czynności, które uczący się musi opanować, aby móc rozwiązać zadanie; oraz

$\rightarrow$ 4. wyniki, tzn. ogólny poziom uczniów i ich zdolność do rozwiązywania zadań, a tym samym wynik pierwszych trzech poziomów.

Rysunek 3. Piramida umiejętności miękkich według Kirkpatricka

\section{WYNIKI}

\section{ZACHOWANIE}

WIEDZA

\section{POSTAWA}

Źródło: Beyond Smiley Sheets: Measuring the ROI of Learning and Development.

Dopiero suma umiejętności zawodowych i umiejętności miękkich daje pełen obraz przygotowania studenta do pracy oraz efektów całego szkolenia, a tym samym pozwala określić poziom ROI - zwrotu $z$ inwestycji w nauczanie, dla każdego indywidualnego interesariusza w procesie uczenia. Aby sprostać zmieniającym się warunkom na rynku 
pracy i zapewnić studentom jak najlepsze możliwości rozwoju zawodowego, musimy zapewnić lepsze wykształcenie.

Elastyczne sposoby uczenia się, które mają swój punkt wyjścia m.in. w indywidualnych umiejętnościach, zainteresowaniach, są niezależne od czasu i miejsca (Malhi 2010). Studenci BBVET mają dostęp do wirtualnej platformy, na której mogą przechowywać swoje dane: z podręczników, instrukcji, zadań, planów nauczania, indywidualnego coachingu, testów i egzaminów, a także filmy i kontakty, oraz korzystać z nich w odpowiednich dla siebie warunkach i czasie.

Przy tworzeniu platformy wykorzystano teorię H. Gardnera siedmiu form inteligencji (+1) i różnych stylów uczenia się, które uczniowie mogą preferować. Są to:

$\rightarrow$ inteligencja językowa i werbalna - uczniowie zdobywają wiedzę, czytając, pisząc i grając w gry werbalne;

$\rightarrow$ inteligencja logiczno-matematyczna - uczniowie koncentrują się bardziej na systemach i figurach, lubią eksperymentować i zadawać pytania;

$\rightarrow$ naturalna mądrość - uczniowie potrafią dobrze rozpoznać i sklasyfikować otaczający ich świat oraz odnaleźć wzorce i konteksty;

$\rightarrow$ inteligencja przestrzenna/wizualna - uczniowie, którzy lubią sztukę, czytają mapy i wykresy oraz myślą obrazami;

$\rightarrow$ inteligencja fizyczna - uczniowie przetwarzają wiedzę poprzez doznania fizyczne i eksplorację otoczenia;

$\rightarrow$ inteligencja muzyczna - uczniowie są wrażliwi na dźwięk w swoim otoczeniu i wolą słuchać muzyki podczas nauki lub czytania;

$\rightarrow$ inteligencja osobista - uczniowie przejawiają dużą pewność siebie i niezależność;

$\rightarrow$ inteligencja społeczna - uczniowie lubią kontakt $z$ innymi ludźmi, mają wielu przyjaciół i biorą udział w zajęciach społecznych. Rozwijają się i lepiej uczą się w grupie.

Mając na uwadze różne rodzaje inteligencji uczniów oraz różne style uczenia, można dobrać odpowiednie techniki, które prowadzą do szybszej nauki i sukcesu ucznia. W programie nauczania wyróżniono kilka typów uczniów:

$\rightarrow$ Reflektor. Motto: „Spójrz na problem z kilku punktów widzenia”. Ulubione pytania: „Może istnieje kilka sposobów, aby to zrobić?". 
$\rightarrow$ Teoretyk. Motto: „Wdrażaj swoją praktykę, używając najlepszej teorii". Ulubione pytanie: „Do czego się to odnosi?".

$\rightarrow$ Pragmatyk. Motto: „Teoria musi działać w praktyce - w przeciwnym razie spróbujemy innej". Ulubione pytanie: „Kiedy można to przełożyć na praktykę?".

$\rightarrow$ Aktywista. Motto: „Działaj-spróbuj!". Ulubione pytania: „Co nowego? Nie powinniśmy po prostu spróbować?".

\section{Metodologia prowadzenia badań}

Badania zostały przeprowadzone wśród interesariuszy kształcenia i szkolenia zawodowego (przedstawicieli szkół oraz pracodawców) oraz studentów kształcenia zawodowego i dotyczyły trzech obszarów, tzw. czytania, pisania i arytmetyki, które są klasyfikowane jako wiedza, współpraca, komunikacja i krytyczne myślenie, uznawane za umiejętności miękkie. Wywiady opierały się na porównywaniu wiedzy z umiejętnościami zdobywanymi w czasie procesu kształcenia. W badaniu główny nacisk położono na to, w jaki sposób instytucje edukacyjne rozwijają swoją ofertę dla uczniów, aby stali się oni wykwalifikowaną kadrą roboczą oraz dobrze funkcjonowali w społeczeństwie. Jakie elementy są potrzebne do aktywnego uczenia się? Jak interesariusze myślą o tym, co zrobić, aby położyć większy nacisk na wiedzę lub umiejętności?

\section{Metodologia badań jakościowych}

Ustrukturyzowany wywiad został przeprowadzony podczas czterech spotkań tzw. RECAP DAYS - dni podsumowujących kolejne etapy edukacji. Dwa pierwsze odbyły się w marcu 2018 r. w Szwecji, trzeci i czwarty w Polsce i na Litwie w maju 2018 r. Przeprowadzono badania na grupie 16 osób z czterech krajów.

\section{Kluczowe odkrycia}

Respondenci podkreślali, że szkoły powinny lepiej przygotowywać uczniów do wejścia na rynek pracy. Zauważono, że obecnie szkoły koncentrują się głównie na trzech wspomnianych obszarach, tj. czytaniu, pisaniu i matematyce, nie wykonując jednocześnie odpowiedniej pracy pod względem aspektów społecznych, współpracy i pracy zespołowej. Rysunek 4 pokazuje, które tematy są najczęściej omawiane i wybierane w szkołach według ekspertów. 
Większość z nich zapytana, dlaczego tak mało czasu poświęca się kompetencjom miękkim, podkreślała nieznajomość metodologii kształcenia u trenerów, brak narzędzi do pomiaru i oceny ich wzrostu oraz niechęć samych uczniów do poszerzania wiedzy w tym zakresie.

Rysunek 4. Lista dyskutowanych tematów w szkole,

zaznaczona jako ważna lub bardzo ważna

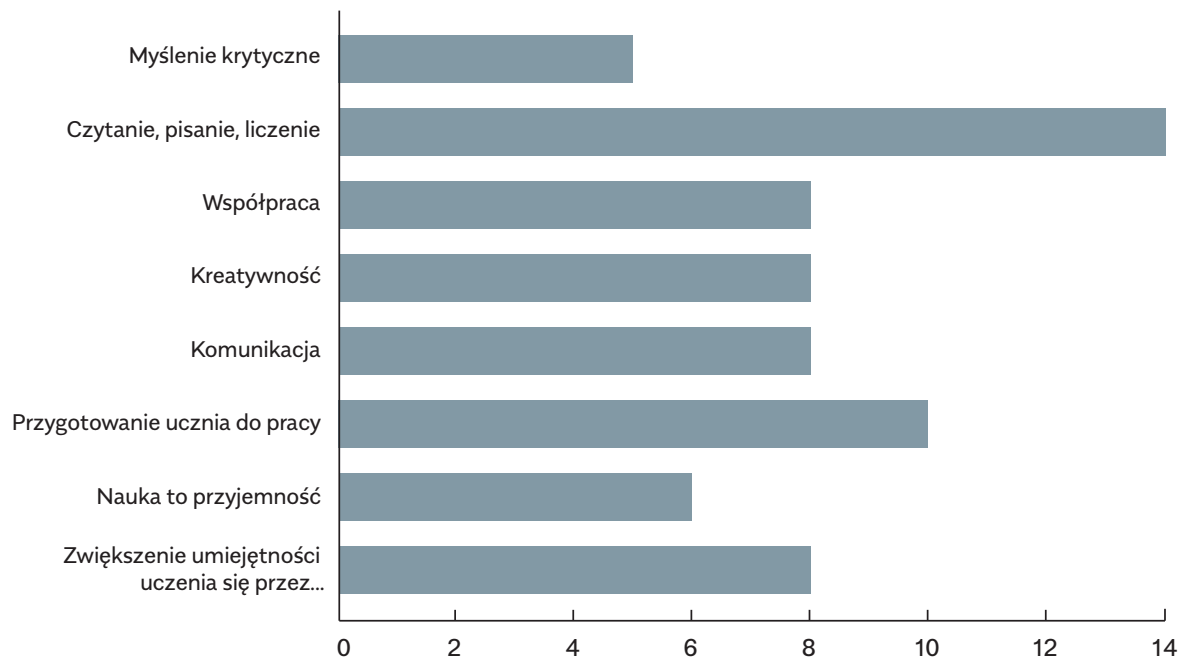

Źródło: opracowanie własne.

Podkreślano, że umiejętność rozwiązywania problemów i współpracy są dwiema najważniejszymi umiejętnościami miękkimi, na których powinna opierać się edukacja.

Wielu respondentów podkreślało, że w tradycyjnym szkolnictwie zawodowym projekty grupowe są realizowane w szkołach, ale brakuje moderowania grupy i wyjaśniania, jak ona funkcjonuje i co dzieje się z nią w czasie. Mimo prób pracy w grupach nadal mamy do czynienia z pracą indywidualną i indywidualnym podejściem do zadań. Zainteresowane strony uważają, że szkoły zbytnio koncentrują się na "nauczaniu na potrzeby testu", pracy w pojedynkę (tylko w pojedynkę) i na indywidualnych osiągnięciach, natomiast praca zespołowa, osiągnięcia grupowe i współpraca z innymi poza klasą są niedoceniane: 10 z 16 ankietowa- 
nych uważa, że zbyt duży nacisk kładzie się na nauczanie, aby zdać obowiązkowe standardowe testy.

Oczywiste jest również, że wiele szkół uważa, że zbytnio skupiają się na osiągnięciach indywidualnych i że uczniowie za dużo pracują sami - 8 z 16 zdecydowanie zgadza się z tym stwierdzeniem.

Zainteresowane strony stwierdziły, że współpraca z innymi uczniami poza klasą jest zbyt mała, zbyt mały nacisk kładzie się na osiągnięcia grupowe i pracę zespołową.

Podkreśliły, że umiejętność współpracy jest kluczowym elementem budowania dojrzałego społeczeństwa i wspierania rozwoju gospodarczego.

Czy w XXI w. technologia może pomóc w nabyciu umiejętności miękkich? Niektóre rodzaje technologii, takie jak komputery czy internet, istnieją od dziesięcioleci i są wykorzystywane w nauczaniu. Technologie cyfrowe dopiero zaczynają docierać do klas za sprawą inicjatyw edukacyjnych wprowadzania nowego sprzętu, cyfrowych publikacji (e-booki) i nowych rodzajów narzędzi oceny. W tym kontekście można powiedzieć, że technologia dopiero wchodzi do edukacji i jest wystarczająco dojrzała, by służyć jako narzędzie do wspólnego uczenia się.

Ankietowani eksperci uważają, że do poprawy sposobu, w jaki umiejętności współpracy są przekazywane osobom uczącym się, potrzeba znacznie więcej niż tylko wdrażania technologii, czyli holistycznego podejścia do edukacji. Na rysunku 5 przedstawiono wymienione przez respondentów czynniki wpływające na poprawę edukacji.

Rysunek 5. Czynniki, które mogą mieć wpływ na współczesną edukację zawodową

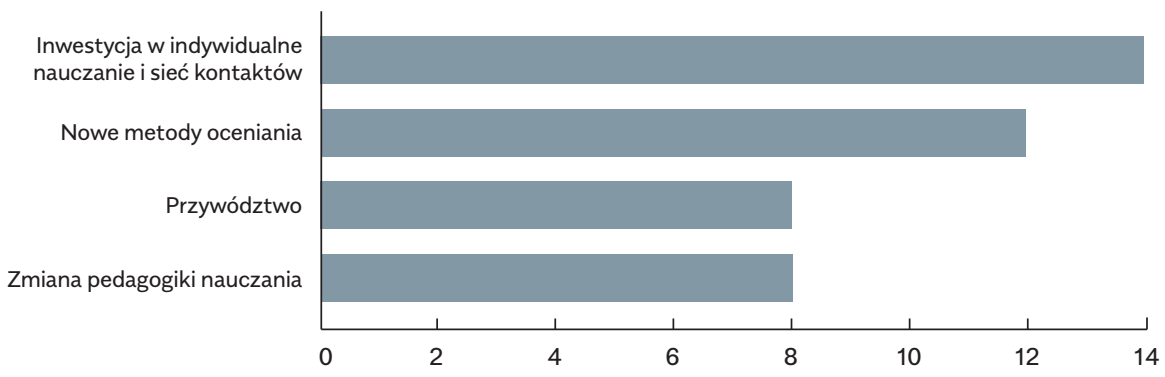

Źródło: opracowanie własne. 


\section{Podsumowanie}

Według badania kadry pracowniczej jest bardzo wiele do zrobienia, aby zwiększyć liczbę dorosłych, którzy pogłębiają swoją wiedzę i uczestniczą w programie uczenia się przez całe życie. Według badania umiejętności osób dorosłych OECD (PIAAC) $20 \%$ populacji aktywnej zawodowo w UE ma niskie umiejętności czytania, pisania i liczenia, a 25\% dorosłych nie posiada umiejętności skutecznego korzystania z technik komputerowych i informacyjnych.

Ostatnie badania przeprowadzone pod kątem kształcenia zawodowego (CEDEFOP 2012) pokazują, że absolwenci europejskiego kształcenia i szkolenia zawodowego odnoszą większe sukcesy w znalezieniu zatrudnienia niż kandydaci z wykształceniem ogólnym. Dotyczy to w szczególności absolwentów programów kształcenia i szkolenia zawodowego o silnej orientacji na miejsce pracy. Te same dane pokazują również, że absolwenci kształcenia i szkolenia zawodowego są lepiej opłacani niż kandydaci z wykształceniem ogólnym. Jednak atrakcyjność i jakość kształcenia i szkolenia zawodowego znacznie różnią się w poszczególnych krajach.

Atrakcyjność kształcenia i szkolenia zawodowego to wielowymiarowa koncepcja, która zależy od unikalnej charakterystyki systemu poszczególnych krajów. Podczas spotkania ekspertów zwołanego przez koordynatora Bałtyckiej Strategii ds. Edukacji Andersa Bergströma, które odbyło się w Ministerstwie Spraw Zagranicznych w Warszawie w maju 2018 r., omawiano sytuację szkolnictwa zawodowego ze szczególnym uwzględnieniem specyfiki Polski. Kształcenie zawodowe w Polsce nie cieszy się dobrą opinią i wybór tej ścieżki edukacyjnej jest traktowany jako życiowa porażka. Podejmowanie kształcenia zawodowego wiąże się ze stereotypami dotyczącymi braku pracy, pieniędzy oraz bardzo nudnego i nieudanego życia, a szkoły zawodowe oferują tradycyjne kierunki studiów, które nie leżą dziś w centrum zainteresowania młodzieży.

Jak wspomniano, kompetencje miękkie są uznawane przez nowoczesnych pracodawców za bardzo ważne w procesie rekrutacji. Jednak w większości przypadków kandydaci nie spełniają wymogów i nie posiadają tych kompetencji. Istnienie dobrze wykwalifikowanej kadry o wysokich kompetencjach międzykulturowych jest wynikiem współpracy między studentami, szkołami i firmami oraz indywidualnego traktowania każdego ucznia. Aby proces nauczania i nabywania kompetencji był jak najbardziej efektywny i elastyczny, autorka na podstawie do- 
świadczeń z projektu BBVET proponuje wykorzystanie następujących elementów przy procesie projektowania i wdrażania nowoczesnego szkolnictwa zawodowego:

$\rightarrow$ nauczanie stacjonarne wzmocnione wirtualną platformą edukacyjną opartą na technologii informatycznej - dostęp niezależny od czasu, miejsca i szybkości nauki;

$\rightarrow$ indywidualne dopasowanie, które zapewnia optymalne efekty uczenia i w rezultacie daje wyniki znacznie lepsze niż przeciętne;

$\rightarrow$ coaching, indywidualne informacje zwrotne i plany działania, które zapewniają monitorowanie postępu w szkoleniu;

$\rightarrow$ rozwój umiejętności miękkich i dostosowanie do różnych rodzajów pracy w przedsiębiorstwach. 